\title{
PEMBATASAN USIA PERTANGGUNGJAWABAN PIDANA ANAK DALAM PERATURAN PERUNDANG-UNDANGAN
}

\author{
THE LIMITATION OF CHILDREN'S CRIMINAL LIABILITY IN INDONESIAN LAW
}

\author{
I Ketut Arjuna Satya Prema, Masruchin Ruba'i, Nurini Aprilianda \\ Program Studi Magister Ilmu Hukum Universitas Brawijaya \\ Jalan M.T. Haryono 169, Malang \\ email: arjuncandika88@gmail.com
}

\begin{abstract}
This article aims to discuss the age of criminal responsibility of children according to statutory regulations in Indonesia and the legis ratio of determining the age of child responsibility according to Law Number 11 of 2012 concerning the Criminal Justice System for Children. The study uses normative legal research with a statutory approach. The results of the study show that three regulations are governing the age limit for a child to be held criminally responsible, namely the Criminal Code Act, Law Number 3 of 1997 concerning Juvenile Court, Law Number 11 of 2011 concerning the Criminal Justice System for Children. These three regulations differ in determining the minimum limit for a child to be held liable for criminal liability. Psychological, sociological, and pedagogical aspects are the base for the ratio of the legal determination of the minimum age of 12 years in the Criminal Justice System for Children.
\end{abstract}

Keywords: child conflict, child crime, child criminal liability

\begin{abstract}
Abstrak: Artikel ini bertujuan untuk membahas tentang usia pertanggungjawaban pidana anak menurut peraturan perundang-undangan di Indonesia dan ratio legis penetapan usia pertanggungjawaban anak menurut Undang-Undang Nomor 11 Tahun 2012 tentang Sistem Peradilan Pidana Anak. Kajian menggunakan penelitian hukum normatif dengan pendekatan perundang-undangan. Hasil kajian menunjukkan terdapat tiga peraturan yang mengatur tentang batas usia seorang anak dapat bertanggung jawab pidana, yaitu Kitab Undang-Undang Hukum Pidana, Undang-Undang Nomor 3 Tahun 1997 tentang Pengadilan Anak, Undang-Undang Nomor 11 Tahun 2011 tentang Sistem Peradilan Pidana Anak. Ketiga peraturan tersebut berbeda dalam menentukan batas minimal anak dapat diminta pertanggungjawaban pidana. Ratio legis penetapan usia minimal 12 tahun pada Undang-Undang Sistem Peradilan Pidana Anak didasarkan pada aspek psikologis, sosiologis, dan pedagogis.
\end{abstract}

Kata Kunci: anak konflik, tindak pidana anak, pertanggungjawaban pidana anak

\section{PENDAHULUAN}

Indonesia merupakan negara hukum (rechtsstaat) sebagaimana dinyatakan dalam Pasal 1 ayat (3) Undang-Undang Dasar Negara Republik Indonesia tahun 1945 (UUD NRI 1945). Pasal tersebut menyatakan secara tegas bahwa Indonesia adalah negara yang berdasarkan hukum, bukan berdasarkan kekuasaan (machsstaat). Gagasan sebagai negara hukum didasarkan pada Pancasila dan UUD NRI 1945 yang berdasar pada nilai ketuhanan, kemanusiaan, persatuan, permusyawaratan, dan keadilan sosial. Dengan ditetapkannya Indonesia sebagai negara hukum maka Indonesia mempunyai kewajiban untuk dapat menjamin dan melaksanakan unsur-unsur keadilan, kemanfaatan, dan kepastian hukum, sesuai dengan tujuan hukum yang diungkapkan oleh Gustav Radburch (Mas, 2011). 
Keadilan merupakan salah satu unsur yang harus dicapai dalam pelaksanaan hukum, keadilan merupakan hal penting yang harus dilindungi oleh negara sebagaimana amanat dari sila kelima Pancasila. Keadilan merupakan fondasi awal untuk menciptakan suatu kenyamanan dalam kehidupan di masyarakat karena hukum akan berjalan dengan baik apabila sesuai dengan nilainilai keadilan yang hidup dalam masyarakat karena keadilan merupakan tujuan utamanya. Hukum harus disesuaikan dengan nilai-nilai yang berlaku dalam suatu bangsa.

Anak merupakan generasi penerus cita-cita perjuangan bangsa sehingga sudah seharusnya mendapatkan perhatian dengan cara mendidik, merawat, membina, dan memberikan kesejahteraan. Karakteristik anak sangat berbeda dengan orang dewasa. Anak perlu mendapatkan perhatian khusus karena kondisi fisik dan mental anak belum sepenuhnya matang. Anak memiliki peran penting dalam keberlangsungan suatu negara karena anak merupakan generasi penerus bangsa.

Perilaku anak sering mengarah pada hal-hal yang negatif. Faktor negatif yang dimaksud adalah dampak negatif dari kemajuan dalam bidang ilmu pengetahuan dan teknologi serta perubahan gaya hidup yang telah membawa perubahan sosial dalam kehidupan masyarakat. Selain hal tersebut, ada faktor penting lain yang mendorong anak untuk melakukan kejahatan yaitu tingkat kemiskinan. Kemisikinan mampu menyebabkan masyarakat serta anak-anak melakukan tindakan-tindakan pidana agar dapat bertahan hidup. Tindak pidana yang dilakukan oleh anak perlu mendapatkan perhatian dari pemerintah karena berakibat buruk bagi masyarakat secara umum dan juga terhadap perkembangan anak itu sendiri pada khususnya (Atmasasmita, 1983).

Instrumen hukum yang mengatur tentang peradilan terhadap anak adalah Undang-Undang Nomor 11 Tahun 2012 tentang Sistem Peradilan Pidana Anak (UU
SPPA). Anak menurut UU SPPA adalah anak yang berkonflik, yaitu anak yang telah berumur 12 tahun tetapi belum berumur 18 tahun yang diduga melakukan tindak pidana. Penjatuhan sanksi kepada anak dipengaruhi oleh usia pada saat anak melakukan tindak pidana (tempus delicti). Ketentuan Pasal 21 UU SPPA, anak yang melakukan kejahatan sebelum berusia 12 tahun dapat dibebaskan dari segala macam bentuk tuduhan tindak pidana. Berdasarkan latar belakang di atas, permasalahan yang akan dibahas dalam tulisan ini adalah pertanggungjawaban pidana bagi anak berdasarkan peraturan perundangundangan dan ratio legis pembatasan usia pertanggungjawaban pidana anak dalam Pasal 21 ayat (1) UU SPPA.

\section{METODE}

Kajian tentang ratio legis pembatasan usia ini menggunakan metode penelitian hukum normatif. Pendekatan yang digunakan adalah pendekatan perundang-undangan. Jenis dan sumber bahan hukum yang digunakan adalah bahan hukum primer, bahan hukum sekunder, dan bahan hukum tersier. Teknik pengumpulan bahan hukum yang digunakan adalah teknik studi literatur. Analisis bahan hukum menggunakan analisis gramatikal dan analisis sistematis.

\section{HASIL DAN PEMBAHASAN}

\section{Pertanggungjawaban Pidana bagi Anak Berdasarkan Peraturan Perundang- Undangan di Indonesia}

Suatu perbuatan yang melanggar peraturan perundang-undangan dapat mendapatkan sanksi atau pidana sebagaimana diatur dalam berbagai peraturan perundangundangan. Namun, terdapat pengecualian yang dapat menyebabkan hilangnya suatu pertanggungjawaban pidana, salah satunya adalah karena usia yang dianggap belum cukup atau masih anak-anak.

Kondisi tersebut sedikit berbeda dengan kasus usia yang menjadi salah satu faktor yang 
mendasari munculnya diskriminasi dalam beberapa bidang kehidupan, khususnya bidang ketenagakerjaan (Awaliyah, Suhariningsih, Budiono, \& Safa'at, 2017). Anak yang karena usianya belum dianggap dewasa tidak dapat dikenai sanksi pidana sedangkan orang dewasa yang karena usianya dianggap tua tidak dapat memilih/mendapatkan pekerjaan sesuai bakat dan minatnya. Berkaitan dengan hal tersebut terdapat tiga peraturan yang mengatur tentang batas usia minimal atau rentang usia seorang anak dapat dikenai sanksi pidana, yaitu Undang-Undang Nomor 1 Tahun 1946 tentang Kitab Undang-Undang Hukum Pidana, Undang-Undang Nomor 3 Tahun 1997 tentang Pengadilan Anak, dan Undang-Undang Nomor 11 Tahun 2012 tentang Sistem Peradilan Pidana Anak.

\section{Pengaturan Pertanggungjawaban Pidana bagi Anak Menurut Undang-Undang Nomor 1 Tahun 1946 Tentang Kitab Undang-Undang Hukum Pidana}

Hukum pidana telah mengatur secara menyeluruh hukum publik untuk mencapai kesejahteraan masyarakat. Penerapan hukum pidana harus berlandaskan asas-asas hukum pidana yang berlaku. Salah satu asasnya adalah asas legalitas, yaitu "Tidak ada suatu perbuatan dapat dipidana kecuali atas kekuatan aturan pidana dalam perundangundangan yang telah ada, sebelum perbuatan dilakukan" (KUHP Pasal 1 ayat (1)).

Perbuatan pidana yang dapat dikenakan sanksi menurut KUHP adalah perbuatan yang mengandung sifat melawan hukum (Prasetyo, 2012). Karenanya tidak mungkin seseorang akan dijatuhi pidana tanpa adanya unsur melawan hukum (Ali, 2011). Seseorang yang memenuhi unsur melawan hukum akan diminta pertanggungjawaban pidana atas tindakan yang telah diperbuat. KUHP mengatur tentang pertanggungjawaban pidana yang tidak dapat dijatuhkan kepada seseorang yang melakukan perbuatan melawan hukum, yaitu apabila: (a) tidak mampu bertanggung jawab, (b) belum mencapai usia 16 tahun, (c) adanya paksaan, (d) pembelaan terpaksa yang melampaui batas, (e) perintah undang-undang, dan (f) melaksanakan perintah jabatan.

Pertanggungjawaban pidana yang dapat dimintai kepada anak diatur dalam Pasal 45, Pasal 46, dan Pasal 47 KUHP. Pasal 45 KUHP mengatur anak di bawah 16 tahun yang melakukan perbuatan pidana akan dikembalikan kepada orang tua, wali, atau yang merawatnya tanpa mendapatkan sanksi apapun. Jika tindak pidana yang dilakukan merupakan pelanggaran dari Pasal 489, 490, 492, 496, 497, 503-505, $514,517-519,526,531,532,536$, dan 540 dan belum lewat dua tahun maka anak yang melakukan perbuatan melawan hukum diserahkan kepada pemerintah. Anak akan dimasukkan ke dalam rumah pendidikan negara atau ditempatkan pada seseorang yang bertempat di Indonesia, badan hukum, yayasan atau lembaga amal yang berkedudukan di Indonesia untuk mendapatkan pendidikan paling lama sampai anak tersebut berusia 18 tahun (KUHP Pasal 1 ayat (1)). Pidana terhadap anak dapat diberikan dengan mengurangi 1/3 dari maksimum pidana pokok (KUHP Pasal 47 ayat (1)). Apabila perbuatan pidana merupakan perbuatan yang dapat diancam dengan pidana mati atau penjara seumur hidup maka pidana yang dapat dijatuhkan paling lama 15 tahun. Pidana yang dapat diberikan kepada anak terbatas pada pidana pokok, sedangkan pidana tambahan tidak dapat dijatuhkan kepada anak.

Kitab Undang-Undang Hukum Pidana Pasal 45, Pasal 46, dan Pasal 47 menunjukkan secara jelas bahwa anak yang belum berusia 16 tahun tidak dikenai pidana kecuali melanggar pasal-pasal yang telah ditentukan dalam pasal 45 KUHP. Menurut Wirjono Prodjodikoro (2003) hakim dapat menjatuhkan putusan yang berisi memerintahkan kepada anak yang melakukan tindak pidana untuk dikembalikan kepada orang tua atau wali tanpa menjatuhkan hukuman pidana apapun 
dan tidak diminta pertanggungjawaban pidananya karena anak tersebut belum mencapai usia 16 tahun.

Pengaturan tentang tindak pidana anak dalam KUHP masih sangat minim, hanya terdapat dalam tiga pasal. Kekurangan dalam penjatuhan pidana terhadap anak adalah: (a) tidak memiliki batas bawah usia yang boleh diminta pertanggungjawaban pidananya, sedangkan dalam The Beijing Rules, memakai konsep batas usia pertanggungjawaban pidana untuk remaja, (b) tidak mengenal lembaga yang melindungi hak-hak anak, (c) aturan-aturan yang terkait dengan anak sangat sederhana sehingga tidak lagi sesuai dengan perkembangan masyarakat Indonesia (Hidaya, 2010).

Kitab Undang-Undang Hukum Pidana yang sudah diundangkan sejak tahun 1946 terlihat sederhana serta menganut tujuan pemidanaan secara absolut, yang bermakna bahwa penjatuhan pidana bertujuan untuk memberikan pembalasan. Hal tersebut tidak cocok untuk diterapkan pada sanksi-sanksi yang terkait dengan anak karena anak belum memiliki emosi yang stabil dan masih dalam tahap berkembang sehingga dalam pemberian sanksi harus lebih mengarah pada pemberian edukasi yang menunjang perkembangan anak.

\section{Pengaturan Pertanggungjawaban Pidana Bagi Anak Menurut Undang-Undang Nomor 3 Tahun 1997 Tentang Pengadilan Anak}

Undang-Undang Pengadilan Anak mulai dibentuk berdasarkan Surat Edaran Kejaksaan Agung Nomor P.1/20 tanggal 30 Maret 1951 yang memberikan penjelasan bahwa yang dimaksud dengan anak nakal adalah mereka yang menurut hukum pidana melakukan perbuatan yang dilarang oleh hukum pidana dan seseorang tersebut belum mencapai usia 16 tahun. Jaksa Agung juga memberikan penekanan terhadap masalah yang berkaitan dengan anak agar tidak langsung menghadapkan anak ke depan pengadilan. Hal tersebut merupakan langkah terakhir (ultimum remedium).

Ide tentang lahirnya peradilan anak di Indonesia sudah ada sejak tahun 1970 dan untuk merealisasikan lahirnya UndangUndang Peradilan Anak di Indonesia, maka pada tanggal 10 November 1995 pemerintah dengan Amanat Presiden Nomor R.12/ PU/XII/1995 mengusulkan Rancangan Undang-Undang Peradilan Anak kepada Dewan Perwakilan Daerah untuk mendapat persetujuannya (Prinst, 2003). Akhirnya Undang-Undang Nomor 3 Tahun 1997 tentang Pengadilan Anak diundangkan pada Lembaran Negara Republik Indonesia Tahun 1997 Nomor 3, Tambahan Lembaran Negara Republik Indonesia Nomor 3668. Berdasarkan ketentuan Pasal 67 UndangUndang Pengadilan Anak maka ketentuan Pasal 45, Pasal 46, dan Pasal 47 tidak berlaku, sedangkan peraturan-peraturan lain yang berkaitan dengan anak tetap berlaku sepanjang tidak bertentangan dengan Undang-Undang Pengadilan Anak (Mulyadi, 2005). Lahirnya Undang-Undang Pengadilan Anak menjadi cerminan pertama peradilan terhadap anak, selain itu Undang-Undang Pengadilan anak memiliki tujuan untuk memperbaiki hukum pidana anak di Indonesia.

Definisi anak menurut Pasal 1 angka 1 Undang-Undang Pengadilan Anak adalah seseorang yang dalam perkara anak nakal telah mencapai umur delapan tahun tetapi belum mencapai umur 18 tahun dan belum pernah kawin. Undang-undang tersebut juga menyebutkan bahwa anak yang melakukan tindak pidana disebut sebagai anak nakal. Penetapan batas usia pertanggungjawaban pidana dalam Undang-Undang Pengadilan Anak (Gultom, 2006) didasarkan pada: (a) secara psikologis, dalam rentang usia tersebut anak dianggap sudah memiliki rasa tanggung jawab, (b) alasan pemaaf apabila anak tersebut belum mencapai usia delapan tahun, (c) peningkatan perlindungan hukum bagi anak, (d) pandangan legislatif, anak yang berumur delapan tahun sudah dapat 
mempertanggungjawabkan perbuatannya, hal tersebut didasarkan pada aspek sosiologis, psikologis, dan pedagogis, (e) ciri dan sifat yang khas dari anak memerlukan pembedaan perlakuan yang bertujuan untuk memberikan pembinaan serta perlindungan yang tepat bagi anak. Usaha pemerintah pada tahun 1957 dengan mengirim beberapa ahli dari beberapa departemen ke luar negeri yang menghasilkan agreement secara lisan antar instansi untuk memberikan perlakuan khusus bagi anak-anak yang melakukan tindak pidana, serta gagasan-gagasan tersebut menjadi ide historis dalam menentukan batas usia pertanggungjawaban pidana anak.

Undang-Undang Pengadilan Anak diujikan ke Mahkamah Konstitusi (MK) dengan Putusan Nomor 1/PUU-VIII/2010 tertanggal 24 Februari 2011 dengan amar putusan bahwa batasan rentang 8-16 tahun yang terdapat dalam UU Peradilan Anak bertentangan dengan UUD NRI 1945 secara bersyarat, kecuali dimaknai 12 tahun. Dasar pertimbangan hakim Mahkamah Konstitusi adalah:

1. "Bahwa Mahkamah berpendapat, batas umur delapan tahun bagi anak untuk diajukan ke sidang dan belum mencapai umur delapan tahun dapat dilakukan pemeriksaan oleh penyidik, secara faktual benar, umur a quo relatif rendah. Penjelasan undangundang a quo menentukan batas umur delapan tahun secara sosiologis, psikologis, pedagogis anak dapat dianggap sudah mempunyai rasa tanggung jawab. Meskipun dalam UU Pengadilan Anak memakai asas praduga tak bersalah, tetapi menurut Mahkamah, fakta hukum menunjukkan adanya beberapa permasalahan dalam proses penyidikan, penahanan, dan persidangan, sehingga menciderai hak konstitusional anak yang dijamin dalam UUD NRI Tahun 1945. Oleh karena hal tersebut, perlu kiranya Mahkamah menetapkan batas umur bagi anak agar dapat memberikan perlindungan terhadap hak konstitusional anak, terutama hak terhadap perlindungan (protection right) dan hak untuk tumbuh dan berkembang (development right), Mahkamah juga berpendapat bahwa konvensi internasional seperti hak-hak anak yang diatur oleh PBB, dan instrumen hukum internasional lainnya yang berhubungan dengan anak, merekomendasikan batas usia pertanggungjawaban anak adalah 12 tahun. Hal tersebut dapat dijadikan tolok ukur dalam menentukan batas usia minimal bagi anak yang dapat dimintai pertanggungjawaban pidananya. Namun, Mahkamah berpendapat bahwa instrumen hukum internasional yang berkaitan dengan anak dan rekomendasi batas usia dari PBB tidak dapat dijadikan sebagai batu uji dalam menilai konstitusionalitas batas usia pertanggungjawaban hukum bagi anak";

2. "Bahwa penetapan usia minimal 12 tahun sebagai ambang batas usia pertanggungjawaban hukum bagi anak telah diterima oleh sebagian negaranegara lainnya dan juga sebagaimana Hak Anak yang diatur oleh PBB dalam General Comment, 10 Februari 2007. Dengan ambang batas usia 12 tahun maka telah sesuai dengan ketentuan tentang pidana yang dapat dijatuhkan kepada anak dalam Pasal 26 ayat (3) dan ayat (4) UU Pengadilan Anak. Penetapan batas usia tersebut juga mempertimbangkan bahwa anak pada umur tersebut secara relatif sudah memiliki rasa emosional, mental dan kondisi psikologis yang stabil serta sesuai dengan budaya bangsa Indonesia, sehingga dapat kiranya memberikan pertanggungjawaban secara hukum karena telah mengetahui hak dan kewajibannya. Selain itu, penetapan batas pertanggungjawaban 
hukum anak dalam usia tersebut sudah sesuai dengan semangat revisi KUHP yang akan menetapkan batasan usia pertanggungjawaban anak yang lebih tinggi, sehingga dapat terhindar dari pelanggaran konstitusional anak sebagaimana dimohonkan oleh para Pemohon yang sama dengan RUU Pengadilan Anak yang menetapkan batas usia pertanggungjawaban adalah 12 tahun. Berdasarkan pandangan hukum di atas, Mahkamah berpendapat bahwa batasan usia minimal 12 tahun lebih memberikan jaminan terhadap hak anak untuk tumbuh dan berkembang serta mendapatkan perlindungan sebagaimana dicita-citakan dalam Pasal 28B ayat (2) UUD NRI Tahun 1945. Dengan demikian, frasa sekurangkurangnya delapan tahun dalam UU Pengadilan Anak adalah inkonstitusional bersyarat, artinya inkonstitusional kecuali harus dimaknai telah mencapai usia 12 tahun sebagai ambang batas minimum seorang anak dapat diminta pertanggungjawaban pidananya."

Setelah adanya putusan MK tersebut maka usia pertanggungjawaban pidana anak yang awalnya delapan tahun berubah menjadi 12 tahun.

\section{Pengaturan Pertanggungjawaban Pidana bagi Anak dalam Perspektif Undang- Undang Nomor 11 Tahun 2012 tentang Sistem Peradilan Pidana Anak}

Permasalahan anak yang berkonflik dengan hukum, baik sebagai korban (victim) maupun anak sebagai pelaku (subjek) tindak pidana, merupakan permasalahan yang sering dihadapi oleh hampir semua negara. Peradilan anak adalah suatu bentuk peradilan secara khusus menangani perkara pidana anak yang tergabung dalam suatu sistem, dikenal dengan sistem peradilan pidana anak yang bertujuan untuk menanggulangi anak agar tidak berkonflik dengan hukum dan melindungi anak yang mengalami konflik hukum (Pangemanan, 2015). UU Sistem Peradilan Pidana Anak (UU SPPA) yang menggantikan UU Pengadilan Anak memberikan definisi dari anak yang berkonflik dengan hukum adalah anak yang sudah berusia 12 tahun tetapi belum mencapai usia 18 tahun yang diduga melakukan tindak pidana. Dari definisi tersebut terlihat jelas bahwa legislatif telah menyepakati usia delapan tahun adalah usia yang belum cocok untuk dapat diminta pertanggungjawaban atas perbuatan yang telah dilakukannya, karena anak yang berusia delapan tahun masih belum mengerti apa yang dilakukannya. Sedangkan anak yang berusia 12 tahun tetapi belum mencapai usia 18 tahun yang diduga melakukan tindak pidana akan tetap dapat diadili di persidangan anak. Lebih jelas dalam Pasal 20 UU SPPA menyebutkan bahwa: "Dalam hal tindak pidana dilakukan oleh anak sebelum genap berumur 18 tahun dan diajukan ke sidang pengadilan anak setelah anak yang bersangkutan melampaui batas umur 18 tahun, tetapi belum mencapai umur 21 tahun, anak tetap diajukan ke sidang anak".

Penggolongan usia anak yang dapat diminta pertanggungjawaban menurut UU SPPA dibagi menjadi tiga, yaitu anak di bawah usia 12 tahun, usia antara 12-14 tahun, dan usia antara 14-18 tahun. Anak yang berusia di bawah 12 tahun dan diduga atau melakukan tindak pidana, maka anak tersebut tidak dapat diminta pertanggungjawaban secara hukum dan anak tersebut dikembalikan kepada orang tua atau walinya. Pasal 21 UU SPPA menyatakan bahwa seorang penyidik, pembimbing kemasyarakatan, dan pekerja sosial profesional mengambil keputusan untuk menyerahkan kembali kepada orang tua/wali atau mengikutsertakannya dalam program pendidikan, pembinaan, dan pembimbingan di instansi pemerintahan atau Lembaga Penyelenggara Kesejahteraan Sosial di instansi yang menangani bidang kesejahteraan sosial, baik di tingkat pusat maupun daerah, paling lama enam bulan. 
Anak yang berusia di antara 12-14 tahun yang melakukan tindak pidana dapat diminta pertanggungjawaban pidana. Anak dalam rentang kategori ini hanya dapat diberikan tindakan sebagaimana bunyi dalam pasal 69 UU SPPA yaitu anak yang belum berusia 14 tahun hanya dapat dikenai tindakan. Anak yang sudah berusia 14-18 tahun dianggap telah dapat memberikan pertanggungjawaban atas tindak pidana yang telah dilakukannya. Anak yang masuk dalam kategori ini sudah dapat divonis berupa hukuman penjara.

\section{Ratio Legis Pembatasan Usia Pertanggung jawaban Pidana Anak Usia di Bawah 12 Tahun yang Melakukan Tindak Pidana Menurut Undang-Undang Nomor 11 Tahun 2012 Tentang Sistem Peradilan Pidana Anak}

Seorang anak tidak dapat melindungi dirinya sendiri dari berbagai ancaman kekerasan yang menimbulkan kerugian mental, fisik, sosial dalam berbagai bidang kehidupan dan penghidupan. Anak harus dibantu oleh orang lain dalam melindungi dirinya, mengingat situasi kondisi dan kondisinya, khususnya dalam pelaksanaan peradilan pidana anak yang asing bagi dirinya. Anak perlu mendapatkan perlindungan dari kesalahan penerapan peraturan perundangundangan yang berpotensi merugikan kondisi fisik, mental, dan sosial anak. Perlindungan anak dalam hal ini disebut dengan perlindungan hukum yuridis (legal protection). Undang-undang pertama yang mengatur secara khusus terkait dengan anak diduga melakukan tindak pidana adalah Undang-Undang Nomor 3 Tahun 1997 tentang Pengadilan Anak. Namun undang-undang tersebut belum mampu untuk mengatasi permasalahan berkaitan dengan anak sehingga dibentuk undangundang baru yang dianggap mampu untuk mengatasi permasalahan terkait dengan anak.

Dasar pemikiran dibentuknya UndangUndang Nomor 11 Tahun 2012 tentang Sistem
Peradilan Pidana Anak sebagai pengganti undang-undang sebelumnya dibagi menjadi tiga, yaitu dasar filosofis, sosiologis, yuridis, dan psikopolitik masyarakat. Dasar filosofis adalah fondasi kehidupan negara Indonesia dalam berbangsa dan bernegara, yaitu Pancasila. Penerapan nilai-nilai Pancasila di dalam suatu hukum mencerminkan suatu keadilan, ketertiban, dan kesejahteraan yang dicita-citakan oleh masyarakat Indonesia.

Dasar sosiologis penyelenggaraan lembaga peradilan pidana anak tidak hanya dapat menguntungkan tetapi juga dapat merugikan kondisi mental, fisik, sosial anak. Tindak pidana anak, saat ini cenderung meningkat dibandingkan dengan tindak pidana lainnya. Hampir semua tindak pidana yang dilakukan oleh orang dewasa juga dilakukan oleh anak-anak. Adapun faktor penyebabnya adalah keadaan sosial ekonomi yang kurang kondusif, pengaruh perkembangan dalam bidang komunikasi dan informasi, hiburan, perkembangan ilmu pengetahuan, dan perubahan gaya hidup. Selain itu, pengaruh dari situasi keluarga juga menjadi faktor yang penting misalnya anak kurang mendapatkan kasih sayang dan perhatian dari keluarganya sehingga anak tersebut dengan mudah terpengaruh oleh hal-hal negatif yang ada dalam lingkungan masyarakat.

Dasar yuridisnya, hukum harus dapat membantu perkembangan manusia ke arah positif dan bersifat adil serta adanya jaminan persamaan. Pasal 28 ayat (2) UUD NRI Tahun 1945 ayat (2) menyatakan bahwa "Setiap anak berhak atas kelangsungan hidup, tumbuh, dan berkembang serta berhak atas perlindungan dari kekerasan dan diskriminasi." Hal yang dicita-citakan oleh Pasal 28 ayat (2) diimplementasikan dalam UU HAM dan UU Perlindungan Anak.

Dasar psikopolitik masyarakat adalah suatu kondisi masyarakat tentang tingkat penerimaan (acceptance) atau tingkat penolakan (resistance) terhadap suatu undangundang. Tindak pidana yang dilakukan oleh 
anak merupakan akibat dari perbuatan yang dilakukan oleh orang dewasa karena anak selalu meniru dan belajar tentang apapun yang dilakukan oleh orang dewasa, padahal anak belum mengetahui antara baik dan buruk. Pandangan ini yang harus ditanamkan dalam masyarakat dan aparatur penegak hukum dalam menangani kasus yang berkaitan dengan anak. Keikutsertaan masyarakat dalam pembentukan suatu produk hukum diharapkan mampu membentuk produk hukum yang sesuai dengan masyarakat dan juga diharapkan mampu menekan tingkat penolakan terhadap produk hukum tersebut, sehingga produk hukum menjadi ideal bagi masyarakat. Keikutsertaan masyarakat dalam proses pembentukannya menjadi faktor penyeimbang dengan komponen pembuat produk hukum lainnya.

Undang-Undang Sistem Peradilan Pidana Anak tidak lagi menyebut anak yang diduga melakukan tindak pidana dengan sebutan anak nakal melainkan disebut dengan anak yang berkonflik dengan hukum. Menurut Pasal 1 angka 3 UU SPPA, anak yang berkonflik dengan hukum adalah anak berusia 12 tahun, tetapi belum berusia 18 tahun yang diduga melakukan suatu tindak pidana. Definisi tersebut menunjukkan bahwa anak yang dapat diminta pertanggungjawaban adalah anak berusia antara 12 tahun sampai 18 tahun. Pasal tersebut memberikan peningkatan usia yang dianggap sebagai anak yang melakukan tindak pidana yang awalnya dalam UU Pengadilan Anak berusia delapan tahun menjadi 12 Tahun. UU SPPA mengatur bahwa penahanan terhadap anak-anak yang berkonflik dengan hukum baru dapat dilakukan setelah anak berusia 14 tahun, sebagaimana ketentuan dari UNICEF yang menetapkan batas usia pertanggungjawaban harus di atas 14 tahun. Hal tersebut didasarkan pada fakta di lapangan yang menunjukkan bahwa sebagian besar negara-negara internasional menetapkan batas usia yang dapat diminta pertanggungjawaban adalah 14 tahun.
Undang-Undang Nomor 3 Tahun 1997 tentang Pengadilan Anak mengatur anak yang dapat diminta pertanggungjawaban pidana adalah anak yang berusia antara 8-18 tahun sedangkan dalam UU SPPA anak yang dapat diminta pertanggungjawaban pidana adalah umur 12-18 tahun. Alasan terjadinya perubahan batas usia tersebut karena dalam beberapa perundang-undangan, batas usia maksimal untuk masuk dalam kategori anak adalah 18 tahun, tetapi tidak ada batasan yang sama dalam mengatur minimum usia anak yang dapat diajukan ke persidangan. Usia delapan tahun merupakan usia yang masih sangat muda dan belum layak untuk dimintai pertanggungjawaban pidana karena pada usia tersebut seorang anak belum menyelesaikan pendidikan dasarnya.

Beijing Rules menegaskan bahwa dalam sistem hukum yang mengakui konsepsi mengenai umur untuk tanggung jawab pidana anak, mulainya umur tersebut tidak ditetapkan pada tingkatan yang terlalu rendah, mengingat kenyataan mengenai kematangan emosional, mental, dan intelektual. Sebagai perbandingan, dapat dilihat aturan batas usia pertanggungjawaban pidana yang dapat diminta ke anak di negara-negara lain (Sambas, 2013), yaitu: (a) di Inggris, batas usia pertanggungjawaban terendah adalah delapan tahun, (b) di Australia, batas usia pertanggungjawaban terendah adalah delapan tahun, (c) di Swedia, batas usia pertanggungjawaban terendah adalah 15 tahun, (d) di Jepang, batas usia pertanggungjawaban terendah adalah 20 tahun, (e) di Colombia, batas usia pertanggungjawaban terendah adalah 18 tahun, dan (f) di Korea, batas usia pertanggungjawaban terendah adalah 14 tahun. Perbedaan batas usia anak yang dapat diminta pertanggungjawaban pidana disebabkan oleh sejarah dan budaya dalam suatu negara. Pertanggungjawaban atas diri anak dapat dinilai dari kematangan moral dan kejiwaan anak. Hal terpenting adalah batas usia pertanggungjawaban pidana anak tidak ditentukan terlalu rendah apalagi tidak 
ditentukan sama sekali karena hal tersebut mengakibatkan gagasan mengenai tanggung jawab menjadi tidak berarti.

UU SPPA Pasal 21 menyatakan bahwa anak yang belum berumur 12 tahun tidak dapat diminta pertanggungjawaban pidana. Dalam penjelasan Pasal 21 dinyatakan bahwa anak yang berusia di bawah 12 tahun belum dapat mempertanggungjawabkan perbuatannya didasarkan pada pertimbangan sosiologis, psikologis, dan pedagogis. Risalah RUU SPPA menjelaskan beberapa pendapat atau alasan yang mendasari anak di bawah usia 12 tahun tidak dapat diminta pertanggungjawaban pidana, yaitu: (a) dalam rentang usia tersebut anak masih membutuhkan pembinaan dari kedua orang tuanya, (b) usia pertanggungjawaban harus didapatkan pada usia yang cukup sehingga anak dapat mengerti konsekuensi tindak pidana yang dilakukannya, (c) dalam rentang usia tersebut kedewasaan emosional, mental dan intelektual anak masih belum stabil, dan (d) menurut Konvensi Hak Anak, minimum usia yang dapat diminta pertanggungjawaban pidana adalah 14 tahun. Ketentuan Pasal 21 UU SPPA sesuai dengan ketentuan Pasal 40 ayat (3) huruf a Konvensi Hak-Hak atas Anak yang menyebutkan bahwa penetapan usia minimum anak-anak merupakan dasar anak tersebut dapat dimintai pertanggungjawaban pidana. Anak di bawah usia minimum yang ditentukan tersebut dianggap tidak memiliki kemampuan untuk melanggar suatu undang-undang.

\section{SIMPULAN}

Penetapan batas usia pertanggungjawaban pidana yang terdapat dalam tiga peraturan yang berlaku di Indonesia berbeda-beda. KUHP menetapkan batas minimal seorang anak dapat diminta pertangungjawaban adalah 16 tahun. Undang-Undang Nomor 3 Tahun 1997 tentang Pengadilan Anak menetapkan usia antara 8-18 tahun. Undang-Undang Nomor 11 Tahun 2012 tentang Sistem Peradilan Pidana Anak menetapkan batas usia yang dapat diminta pertanggungajwaban pidana adalah usia antara 12-18 tahun. Rasio legis pembentukan Undang-Undang dalam menetapkan Pasal 21 ayat (1) UU SPPA adalah bahwa anak yang masih belum berusia 12 tahun dianggap tidak mampu untuk bertanggungjawab secara pidana yang didasarkan pada: (a) pertimbangan sosiologis, psikologis dan pedagogis, (b) anak yang belum berusia 12 tahun dan dalam rentang usia 12-18 tahun masih memerlukan pembinaan orang tuanya, (c) usia yang cukup untuk anak dapat mengerti terhadap konsekuensi tindak pidana yang dilakukan, dan (d) rentang usia 12-18 tahun belum memiliki kedewasaan emosional, mental dan intelektual.

\section{DAFTAR RUJUKAN}

Ali, M. (2011). Dasar-Dasar Hukum Pidana. Jakarta: Raja Grafindo.

Atmasasmita, R. (1983). Problem Kenakalan Anak-Anak Remaja. Bandung: Armico.

Awaliyah, S., Suhariningsih., Budiono, A.R. \& Safa'at, R. (2017). Law Review on Age Discrimination for Job Seekers in Indonesia. Journal of Law, Policy and Globalization., 63, 109.

Gultom, M. (2006). Perlindungan Hukum Terhadap Anak. Bandung: Refika Aditama.

Hidaya, B. (2010). Pemidanaan Anak di Bawah Umur. Bandung: Alumni.

Mas, M. (2011). Pengantar Ilmu Hukum. Bogor: Ghalia.

Mulyadi, L. (2005). Pengadilan Anak di Indonesia. Bandung: Mandar Maju.

Pangemanan, J. B. (2015). Pertanggungjawaban Pidana Anak Dalam Sistem Peradilan Pidana Indonesia. Lex Et Societatis, III(1).

Prasetyo, T. (2012). Hukum Pidana. Jakarta: Raja Grafindo.

Prinst, D. (2003). Hukum Anak Indonesia. Bandung: Citra Aditya Bakti.

Prodjodikoro, W. (2003). Asas-Asas Hukum Pidana di Indonesia. Bandung: Refika 
Aditama.

Republik Indonesia. (1945). Undang-Undang Dasar Negera Republik Indonesia Tahun 1945.

Republik Indonesia. (1946). Undang-Undang Nomor 1 Tahun 1946 Tentang Kitab Undang-Undang Hukum Pidana.

Republik Indonesia. (2012a). Naskah Akademik Undang-Undang Nomor 11 Tahun 2012 Tentang Sistem Peradilan Pidana Anak.

Republik Indonesia. (2012b). UndangUndang Nomor 11 Tahun 2012 Tentang
Sistem Peradilan Pidana Anak. Risalah Rapat Kerja Panitia Khusus Rancangan Undang-Undang Peradilan Anak. (1996).

Risalah Undang-Undang Nomor 11 Tahun 2012 Tentang Sistem Peradilan Pidana Anak. (2012).

Sambas, N. (2013). Peradilan Pidana Anak di Indonesia dan Instrument Internasional Perlindungan Anak Serta Penerapannya. Yogyakarta: Graha Ilmu. 